\title{
Bioavailability and tissue distribution of Dechloranes in wild frogs (Rana limnocharis) from an e-waste recycling area in Southeast China
}

\author{
Long Li, Wenyue Wang, Quanxia Lv, Yujie Ben, Xinghong Li* \\ State Key Laboratory of Environmental Chemistry and Ecotoxicology, Research Center of Eco-Environment Sciences, Chinese Academy of Sciences, \\ Beijing 100085, China. E-mail: lijinglong.88@163.com
}

\section{A R T I C L E I N F O}

\section{Article history:}

Received 22 April 2013

revised 23 May 2013

accepted 04 July 2013

\section{Keywords:}

dechlorane plus and its analogs

e-waste

wild frogs

DOI: $10.1016 /$ S1001-0742(13)60447-7

\begin{abstract}
A B S T R A C T
Dechlorane Plus (DP), a flame retardant used as an alternative to decabromodiphenylether, has been frequently detected in organisms, indicating its bioaccumulation and biomagnification potential in aquatic and terrestrial species. However, little data is available on the bioaccumulation of DP in amphibians. Dechlorane Plus and its analogs (DPs) were detected in the liver, muscle and brain tissues of wild frogs (Rana limnocharis), which were collected from an e-waste recycling site, Southeast China. DP, Mirex, Dec 602 and a dechlorinated compound of DP (anti-Cl $1_{11}$-DP) varied in the range of 2.01-291, 0.650-179, 0.260-12.4, and not detected (nd)-8.67 ng/g lipid weight, respectively. No difference of tissue distribution was found for syn-DP, Mirex and Dec 602 between the liver and muscle tissue (liver/muscle concentration ratio close to $1, p>0.05$ ). However, higher retention was observed for anti-DP and anti-Cl $\mathrm{Cl}_{11}$-DP in the frog muscle relative to the liver tissue (liver/muscle concentration ratio $<1, p<0.05$ ). Additionally, the blood-brain barrier was found to work efficiently to suppress these compounds entering brain tissues in this species (liver/brain concentration ratio $>1, p<0.05$ ), and the molecular weight was a key factor impacting the extent of the blood-brain barrier. Compared to levels in the muscle and brain tissue, a preferential enrichment of syn-DP was observed in the liver tissue, suggesting the occurrence of stereo-selective bioaccumulation in the wild frog.
\end{abstract}

\section{Introduction}

Dechloranes (DPs) are a series of highly chlorinated flame retardants (HFRs) including Mirex, Dechlorane Plus (DP), Dechlorane 602 (Dec 602), Dechlorane 603 (Dec 603) and Dechlorane 604 (Dec 604). Due to their excellent thermal stability and flame resistance, they have been widely used in many materials, such as electrical wire and cable coating, plastic materials and other polymeric systems (Sverko et al., 2011). Of these, DP has been classified as a high production volume chemical (HPV) in the United States, and also listed on Canada's Domestic Substances Lists (Sverko et al., 2010).

To date, research has been conducted to investigate the

\footnotetext{
${ }^{*}$ Corresponding author. E-mail: 1xhzpb@ @rcees.ac.cn
}

occurrence and fate of DPs in wildlife, such as shellfish (Tomy et al., 2007; Jia et al., 2011; Schlabach, 2011), fish (Kang et al., 2010; Wu et al., 2010; Schlabach, 2011; Zhang et al., 2011a; Peng et al., 2012; Subring et al., 2013), terrestrial and aquatic birds or bird eggs (Gauthier et al., 2007; Guerra et al., 2011; Zhang et al., 2011b; Sun et al., 2012), indicating that DP is readily accumulated within biological tissues. Species-specific enrichment of either $s y n$-DP or anti-DP was also observed in previous studies. Syn-DP was observed to be more bioaccumulative than anti-DP in aquatic biota, while no isomer discrimination was found in terrestrial biota (Xian et al., 2011). Recently, the products of dechlorinated DP including anti-Cl $\mathrm{Cl}_{10}$-DP and anti-Cl $\mathrm{Cl}_{11}$-DP, were also observed in birds (Guerra et al., 2011; Sun et al., 2012), fishes (Zhang et al., 2011a; Peng et al., 2012) and human tissues (Ren et al., 2009; Zheng et al., 2010; Ben et al., 2013). 
Due to their aquatic and terrestrial habitats, amphibian animals have unique bioaccumulation properties for pollutants (Wu et al., 2009), and have been used as important environmental bioindicators (Burkhart et al., 2000). As a kind of amphibians, frogs have been used to assess various pollutants in the environment, such as polybrominated diphenyl ethers (PBDEs) (Wu et al., 2009; Liu et al., 2011), polybrominated biphenyl (PCBs) (Pezdirc et al., 2011), perfluorooctane sulfonate (PFOS) (Kannan et al., 2005) and organochlorine pesticides (OCPs) (de Solla et al., 2002; Wu et al., 2012). These studies revealed the bioaccumulation of pollutants in frogs and different enrichment characteristic in the biota (Wu et al., 2009). To date, some published literature on DP and its analogs in aquatic and terrestrial biota has appeared, but data on DP bioaccumulation in frogs is unavailable. To fully understand the migration and transformation of DP in wildlife, the bioavailability and tissue distribution of DPs were examined in the liver, muscle and brain tissues of wild frogs (Rana limnocharis) from an e-waste recycling site in Southeast China. PBDEs and PCBs were detected simultaneously to help understand the contamination status and possible tissue distribution mechanism of Dechloranes.

\section{Materials and methods}

\subsection{Chemicals and materials}

Stock solutions including syn-DP $(100 \mu \mathrm{g} / \mathrm{mL})$, anti-DP $(100 \mu \mathrm{g} / \mathrm{mL}),{ }^{13} \mathrm{C}_{10}$-labelled syn-DP $(100 \mu \mathrm{g} / \mathrm{mL}),{ }^{13} \mathrm{C}_{10^{-}}$ labelled anti-DP $(100 \mu \mathrm{g} / \mathrm{mL}),{ }^{13} \mathrm{C}_{12}$-labelled PCB-208 (40 $\mu \mathrm{g} / \mathrm{mL})$, method 1614 native PAR stock solution EO-5278 (unlabeled BDE-28, 47, 99, 100, 153, 154, 183, $1 \mu \mathrm{g} / \mathrm{mL}$; BDE-209, $10 \mu \mathrm{g} / \mathrm{mL})$, BDE-77 $(50 \mu \mathrm{g} / \mathrm{mL}),{ }^{13} \mathrm{C}_{12}$-labelled BDE-209 $(50 \mu \mathrm{g} / \mathrm{mL})$ and ${ }^{13} \mathrm{C}_{12}$-labelled PCB mixture EC-4058 $\left({ }^{13} \mathrm{C}_{12}\right.$-labelled CB-28, 52, 101, 138, 153, 180, 209, $5 \mu \mathrm{g} / \mathrm{mL}$ ), were obtained from Cambridge Isotope Laboratories Inc. (Andover, USA). Stock solutions of anti$\mathrm{Cl}_{10}$-DP $(50 \mu \mathrm{g} / \mathrm{mL})$, anti-Cl 11 -DP $(50 \mu \mathrm{g} / \mathrm{mL})$ and Mirex $(100 \mu \mathrm{g} / \mathrm{mL})$ were purchased from Wellington Laboratories Inc. (Guelph, ON, Canada). Dec 602 (10 mg) was purchased from Toronto Research Chemical Inc. (North York, ON, Canada). Unlabelled PCB mixtures (C-SCA$06,10 \mu \mathrm{g} / \mathrm{mL}$ ) containing 32 components were supplied by AccuStandard Inc. (New Haven, CT, USA).

Dichloromethane (DCM, J.T. Baker, Deventer, the Netherlands) and $n$-hexane (Hex, Thermo Fisher Scientific, Pittsburgh, PA, USA) were pesticide grade, and other solvents, including methanol and ethanol (Thermo Fisher Scientific), methyl tertiary butyl ether (MtBE, Tedia Company Inc., Fairfield, OH, USA) and isopropanol (J.T. Baker) were High Performance Liquid Chromatography grade. Silica gel (60-100 mesh) was purchased from Merck KGaA (Darmstadt, Germany) and activated at $550^{\circ} \mathrm{C}$ for
$6 \mathrm{hr}$ in a muffle furnace before use. Concentrated $\mathrm{H}_{2} \mathrm{SO}_{4}$ was obtained from Sinopharm Chemical Reagent Co. Ltd. (Beijing, China). Sodium sulfate anhydrous $\left(\mathrm{Na}_{2} \mathrm{SO}_{4}\right.$ granular, purity $>99.5 \%$ ) was supplied by Jinke Refined Chemical institutes (Tianjin, China).

\subsection{Sample collection}

The sampling sites were located in Taizhou City, Zhejiang Province, China, which is a major e-waste recycling center in Southeast China. Wenling, Luqiao and Linhai are three main towns included in Taizhou City. Numerous villages in Wenling and Luqiao (including TS, NW, ZG and HMQ) have been heavily involved in recycling e-wastes containing PBDEs and PCBs since the late 1970s. The three villages of TS, NW and ZG are situated in Wenling Town and HMQ Village is in Luqiao Town. Both NW and TS are e-waste recycling villages, and e-waste recycling activities are prevalent in NW to date. Both ZG and HMQ are traditional villages that have participated in recycling of obsolete electric capacitors, electric generators, and cable wires since the 1970s. Although e-waste recycling operations were prohibited in Linhai Town, a brick kiln with e-waste plastic powder used as brick material was found recently in the LH Village.

Rana limnocharis (body length: 27-42 mm) were collected in five sampling sites (TS, NW, ZG, HMQ and LH) in July, 2012. After euthanasia, the liver, the hind leg muscle and the brain tissues were excised from each frog. Considering the small amount of tissue samples (especially brain tissue), the same tissue of frogs in the designated spots were combined as one pooled sample (53, 33, 33, 18, 22 frogs for TS, NW, ZG, HMQ and LH, respectively). After being homogenized, the pooled tissue samples were freeze-dried, and then kept frozen at $-20^{\circ} \mathrm{C}$ until analysis.

\subsection{Sample extraction, clean-up, and analysis}

After the internal standards (including ${ }^{13} \mathrm{C}_{10}$-labeled synDP, ${ }^{13} \mathrm{C}_{10}$-labeled anti-DP, BDE $77,{ }^{13} \mathrm{C}_{12}$-labeled BDE $209,{ }^{13} \mathrm{C}_{12}$-labeled PCB mixture EC-4058) were spiked, tissue samples were extracted ultrasonically three times with $20 \mathrm{~mL}$ of $1: 1: 1 \mathrm{MtBE}: H e x: D C M(V: V: V)$. An aliquot of the extract was used for the determination of lipid by gravimetry. The remaining extract was cleaned up in a chromatography column $(30 \mathrm{~cm} \times 10 \mathrm{~mm}$ ID) containing $1 \mathrm{~g}$ activated silica gel, $8 \mathrm{~g}$ sulfuric acid silica (30\% acid by weight) and $2.5 \mathrm{~g} \mathrm{Na}_{2} \mathrm{SO}_{4}$, and was washed with 100 $\mathrm{mL}$ hexane. The final eluate was concentrated and a known amount of the injection internal standard $\left({ }^{13} \mathrm{C}_{12}\right.$-labeled PCB-208) was added prior to the GC/MS analysis.

The quantification of $s y n-\mathrm{DP}$, anti-DP, anti-Cl $\mathrm{Cl}_{10}-\mathrm{DP}$, anti- $\mathrm{Cl}_{11}$-DP, Mirex, Dec 602 and PBDEs was performed using an Agilent $6890 \mathrm{GC}$, coupled with a 5973 MSD in electron capture negative ionization (ECNI) mode. The separation was processed using a fused silica capillary column (RTX-1614, $30 \mathrm{~m} \times 0.25 \mathrm{~mm}$ ID and $0.1 \mu \mathrm{m}$ film 
thickness). The carrier gas used was helium with a flow rate of $1.0 \mathrm{~mL} / \mathrm{min}$, and methane was used as the reaction gas. The GC oven temperature was programmed as follows: the initial temperature was $100^{\circ} \mathrm{C}$ maintained for $2 \mathrm{~min}$, which was then increased to $250^{\circ} \mathrm{C}$ at a rate of $25^{\circ} \mathrm{C} / \mathrm{min}$, followed by a $1.5^{\circ} \mathrm{C} / \mathrm{min}$ rise to $260^{\circ} \mathrm{C}$, and finally the temperature was increased at a rate of $25^{\circ} \mathrm{C} / \mathrm{min}$ to achieve the final temperature of $315^{\circ} \mathrm{C}$, which was maintained for $7 \mathrm{~min}$. The injector, transfer line, and ion source temperatures were 250,280 , and $150^{\circ} \mathrm{C}$, respectively. The monitored ion fragments were $\mathrm{m} / \mathrm{z} 475.7$ and 477.7 for ${ }^{13} \mathrm{C}_{12}$-labeled CB-208; $\mathrm{m} / \mathrm{z} 583.7$ and 585.7 for anti-Cl $\mathrm{Cl}_{10^{-}}$ DP; $m / z 617.7$ and 619.7 for anti-Cl $\mathrm{Cl}_{11}$-DP; $m / z 651.7$ and 653.7 for $s y n$-DP and $a n t i-\mathrm{DP} ; \mathrm{m} / \mathrm{z} 661.7$ and 663.7 for ${ }^{13} \mathrm{C}_{10}$-labeled syn-DP and ${ }^{13} \mathrm{C}_{10}$-labeled anti-DP, $\mathrm{m} / \mathrm{z}$ 494.7 and 496.7 for ${ }^{13} \mathrm{C}_{12}$-labeled BDE209, and $\mathrm{m} / \mathrm{z} 79$ and 81 for PBDEs.

As for PCBs, GC/MS was employed in electron impact ionization mode (EI) with a DB-5 MS column $(30 \mathrm{~m} \times 0.25$ $\mathrm{mm}$ internal diameter and $0.25 \mu \mathrm{m}$ film thickness). The GC oven temperature was programmed as follows: the initial temperature was $120^{\circ} \mathrm{C}$ maintained for $1 \mathrm{~min}$, which was then increased to $150^{\circ} \mathrm{C}$ at a rate of $30^{\circ} \mathrm{C} / \mathrm{min}$, followed by a $2.5^{\circ} \mathrm{C} / \mathrm{min}$ rise to $280^{\circ} \mathrm{C}$. The injector, transfer line, and ion source temperatures were 290,280 , and $230^{\circ} \mathrm{C}$, respectively. The ion fragments were monitored as follows: $\mathrm{m} / \mathrm{z} 268$ and 270 for ${ }^{13} \mathrm{C}_{12}$-labeled CB-28, $\mathrm{m} / \mathrm{z} 304$ and 302 for ${ }^{13} \mathrm{C}_{12}$-labeled CB-52, $\mathrm{m} / \mathrm{z} 338$ and 340 for ${ }^{13} \mathrm{C}_{12-}$ labeled CB-101, $m / z 372$ and 374 for ${ }^{13} \mathrm{C}_{12}$-labeled PCB138 and $153, m / z, 406$ and 408 for ${ }^{13} \mathrm{C}_{12}$-labeled CB-180, $\mathrm{m} / \mathrm{z} 510$ and 508 for ${ }^{13} \mathrm{C}_{12}$-labeled CB-209; $\mathrm{m} / \mathrm{z} 256$ and 258 for CB-28, $m / z 292$ and 290 for CB-52, 66 and 74, $\mathrm{m} / \mathrm{z}$ 326 and 328 for CB-101, 105 and $118, m / z 360$ and 362 for CB-138, 153 and 156, $\mathrm{m} / \mathrm{z} 394$ and 396 for CB-170, 180 and $187, m / z 498$ and 496 for CB-209.

\subsection{Quality control}

Laboratory procedure blanks were analyzed by the same method as real samples. No target compound was found in the procedure blanks. The recoveries of the internal standards were $77.9 \%-117.0 \%$ for ${ }^{13} \mathrm{C}_{10}$ syn-DP, 76.6\%-123.9\% for ${ }^{13} \mathrm{C}_{10}$ anti-DP, $94.0 \%-124.6 \%$ for ${ }^{13} \mathrm{C}_{12}$ PCBs (EC-4058), 73.9\%-105.2\% for BDE-77 and $35.4 \%-131.9 \%$ for ${ }^{13} \mathrm{C}_{12}$ BDE-209. The limits of detection (LODs) were defined as the concentration of target compounds in a sample producing a peak in the chromatogram with a signal-to-noise ratio of 3 , and LODs for PCBs, PBDEs, Mirex, Dec 604, syn-DP, anti-DP and anti-Cl $\mathrm{Cl}_{11}$ DP was 0.32-0.87, 0.37-2.54, 0.34, 0.036, 0.096, 0.19, $0.049 \mathrm{ng} / \mathrm{g}$ lipid weight (lw), respectively. If the detected amount was lower than the LODs, it was considered to be not detected (ND).

\section{Results and discussion}

\subsection{Levels and pollution conditions}

Dechloranes (including Mirex, syn-DP, anti-DP, Dec 602, anti-Cl $\mathrm{Cl}_{11}$-DP), eight PBDE congeners (BDE-47, 99, 100, 153, 154, 183, 197, 209), and fourteen PCB congeners (CB-28, 52, 66, 74, 101, 105, 118, 138, 153, 156, 170, $180,187,209)$ were detected in frog liver, muscle and brain tissues. The levels of all compounds in different tissues of frogs were described based on lw and wet weight (ww) (Table 1).

DP was detected in all tissue samples of frogs. As far as dechlorinated compounds of DP, anti- $\mathrm{Cl}_{10}$-DP was not found in any tissues, but anti-Cl $\mathrm{Cl}_{11}$-DP was detectable in all of the liver tissues and the muscle tissues, and four of five brain tissues (Table 1). To date, there has been no report on DP and anti- $\mathrm{Cl}_{11}$-DP in amphibians, but several studies on biota were available. It can be seen that the concentration of DP in frogs was generally higher than those in the terrestrial and aquatic biota from most of the regions in the world (Feo et al., 2012). However, the DP level in an aquatic food web (including Chinese mystery snail, prawn, mud carp, northern snakehead and water snake) from Qingyuan, another e-waste recycling site in South China, ranged from 19-9630 ng/g lw (Wu et al., 2010). Zhang et al. (2011b) reported DP in water bird muscle from the same region (Qingyuan) with values ranging from nd-610 ng/g lw. DP was also observed in the Laurentian Great Lakes basin of North America at concentrations ranging 1.5-4.5 ng/g ww in herring gull eggs, and $0.063-2.6 \mathrm{ng} / \mathrm{g} \mathrm{lw}$ in fishes (lake trout and whitefish), respectively (Gauthier et al., 2007; Shen et al., 2010). It seemed that the DP level in this study was in the same range as those in the biota collected from other e-waste recycling regions, and comparable to and/or higher than those from near a Dechloranes Manufacturing Plant in North America. Reports on anti- $\mathrm{Cl}_{11}$-DP in biota were limited. The concentration of anti- $\mathrm{Cl}_{11}$-DP in frogs was in the range as that found in bottom fishes from another electronic waste recycling site of China (0.08$10.14 \mathrm{ng} / \mathrm{g}$ ww in liver, nd-0.06 ng/g ww in muscle and nd-0.46 ng/g ww in brain) (Zhang et al., 2011a), and was comparable with levels in terrestrial passerine birds from the Pearl River Delta, one of the most populous and important economic regions in China (nd-7.5 ng/g lw in liver and nd-7.1 ng/g lw in muscle) (Sun et al., 2012), and was also of the same magnitude as that in Peregrine Falcon eggs (geometric mean: $1.84 \mathrm{ng} / \mathrm{g} \mathrm{lw}$ ) collected from a nearby Dechloranes Manufacturing Plant (Guerra et al., 2011). However, it was one order of magnitude higher than that in Chinese sturgeon collected from the Yangtze River (median: $1.9 \mathrm{pg} / \mathrm{g}$ ww in liver and $0.5 \mathrm{pg} / \mathrm{g}$ ww in muscle), which supplies freshwater for the second largest metropolis in China, Shanghai (Peng et al., 2012). Clearly, the comparison indicates the occurrence of serious DP and 
Table 1 Concentrations (ng/g lipid weight) of Dechloranes, PBDEs and PCBs in different tissues of frogs (pg/g wet weight in brackets)

\begin{tabular}{|c|c|c|c|c|c|c|c|c|}
\hline Site & Specimen & $\sum$ PBDEs & $\sum \mathrm{PCBs}$ & Mirex & Dec 602 & $\sum \mathrm{DP}$ & anti- $\mathrm{Cl}_{11}-\mathrm{DP}$ & $f_{\text {anti }}$ \\
\hline \multirow{3}{*}{ TS } & Liver & 118 (3696) & $515(16207)$ & $11.5(361)$ & $0.750(23.5)$ & 3.28 (103) & $0.160(4.88)$ & 0.64 \\
\hline & Muscle & 207 (1612) & 929 (7239) & 14.7 (114) & $1.03(8.04)$ & $8.25(64.2)$ & $0.310(2.42)$ & 0.76 \\
\hline & Brain & $59.2(2576)$ & $229(9962)$ & $2.23(97.0)$ & $0.340(14.9)$ & 2.64 (1158) & $0.0700(2.99)$ & 0.79 \\
\hline \multirow{3}{*}{ NW } & Liver & 1005 (27732) & 989 (27328) & 179 (4948) & $11.4(313)$ & 197 (5427) & $6.01(1656)$ & 0.64 \\
\hline & Muscle & $1202(8534)$ & $1283(9124)$ & 155 (1097) & $12.4(87.8)$ & 191 (1355) & $5.35(38.0)$ & 0.66 \\
\hline & Brain & $310(16627)$ & 391 (20962) & $8.26(443)$ & $0.730(39.3)$ & $15.2(815)$ & $0.350(18.6)$ & 0.66 \\
\hline \multirow{3}{*}{$\mathrm{ZG}$} & Liver & $426(14930)$ & $1373(48145)$ & $8.53(299)$ & $5.14(180)$ & $151(5290)$ & $3.69(129)$ & 0.52 \\
\hline & Muscle & 954 (9313) & $1428(13976)$ & $9.08(88.7)$ & $5.85(57.1)$ & $291(2838)$ & $8.67(84.7)$ & 0.83 \\
\hline & Brain & 115 (6396) & 139 (7776) & $1.28(71.4)$ & $1.02(57.1)$ & $25.0(1395)$ & $0.350(19.4)$ & 0.59 \\
\hline \multirow{3}{*}{ HMQ } & Liver & 320 (2689) & 12142 (101913) & $89.4(751)$ & $3.46(29.0)$ & $49.0(411)$ & $1.74(14.6)$ & 0.56 \\
\hline & Muscle & 466 (1312) & $16788(47250)$ & $89.5(252)$ & $3.74(10.5)$ & $126(354)$ & $5.03(14.2)$ & 0.88 \\
\hline & Brain & $84.0(1059)$ & 2265 (28538) & $11.1(140)$ & $0.880(11.0)$ & $10.1(127)$ & $0.140(1.79)$ & 0.76 \\
\hline \multirow{3}{*}{ LH } & Liver & $212(4440)$ & 97.7 (2087) & $9.51(199)$ & $0.92(19.16)$ & $4.67(97.6)$ & $0.130(2.72)$ & 0.72 \\
\hline & Muscle & $452(1755)$ & $90.6(352)$ & $6.28(24.4)$ & $1.49(5.79)$ & $114(444)$ & $4.61(17.9)$ & 0.96 \\
\hline & Brain & $44.2(1781)$ & nd & $0.650(26.2)$ & $0.260(10.5)$ & $2.01(80.9)$ & nd & 0.77 \\
\hline
\end{tabular}

nd: not detected.

$\sum$ PBDEs: sum of BDE-47, 99, 100, 153, 154, 183, 197, 209; $\sum$ PCBs: sum of CB-28, 52, 66, 74, 101, 105, 118, 138, 153, 156, 170, 180, 187, 209; $\sum \mathrm{DP}$ : sum of syn-DP and anti-DP.

anti- $\mathrm{Cl}_{11}$-DP pollution in wildlife in China, especially in e-waste recycling areas.

Both Mirex and Dec 602 were detected in all tissues of frogs, implying their widespread occurrence in the studied region. Recently, both were observed in Chinese sturgeon (median: $15 \mathrm{pg} / \mathrm{g}$ ww in liver and $5.4 \mathrm{pg} / \mathrm{g} \mathrm{ww}$ in muscle for Mirex, and $9.7 \mathrm{pg} / \mathrm{g}$ ww in liver and $0.4 \mathrm{pg} / \mathrm{g}$ ww in muscle for Dec 602, respectively) (Peng et al., 2012) and peregrine falcon eggs in the Canadian Great Lakes (641 ng/g lw for Mirex, $73.2 \mathrm{ng} / \mathrm{g}$ lw for Dec 602, respectively) (Guerra et al., 2011). It can be seen that Mirex and Dec 602 levels in our study were much higher than those in Chinese sturgeon in the Yangtze River, but comparable to those in peregrine falcon eggs in the Canadian Great Lakes. Compared with the DP levels in the frogs (Table 1), although both Mirex and Dec 602 were relatively lower, their occurrence in the wildlife from e-waste recycling sites should be of concern due to their relatively higher bioaccumulation potential (Shen et al., 2011; Peng et al., 2012).

Both PCBs and PBDEs were also detected in most of frog tissues (Table 1). Previous studies conducted in biota collected from the Taizhou region revealed serious contamination with PBDEs and PCBs. For example, PBDEs level in wild frogs was found with the mean values of 28.38 $\mathrm{ng} / \mathrm{g} \mathrm{ww}$ in liver and $17.10 \mathrm{ng} / \mathrm{g} \mathrm{ww}$ in brain (Liu et al., 2011), and the average level of PCBs was $5445.34 \mathrm{ng} / \mathrm{g}$ $\mathrm{lw}$ in muscle of crucian carp, and $1303.53 \mathrm{ng} / \mathrm{g}$ lw in field snails (Zhang et al., 2009), which was comparable to our result. However, it seemed that concentrations of PBDEs and PCBs were 1-2 orders of magnitude higher than those of DPs found in the same specimen.

\subsection{Liver, muscle and brain tissue distribution}

As an important component of toxicological studies, tissue distribution can help us to understand the migration and transformation of pollutants in biota, and preliminarily to identify the possible target organs of the toxic effects (Peng et al., 2012). In order to compare the tissue bioaccumulation of DPs in frogs, lipid-normalized concentration ratios of liver/muscle (L/M) and of liver/brain (L/B) were calculated for syn-DP, anti-DP, Mirex, Dec 602 and anti$\mathrm{Cl}_{11}$-DP. For the $\mathrm{L} / \mathrm{M}$ ratio, the geometric mean values of syn-DP, anti-DP, Mirex, Dec 602 and anti-Cl $\mathrm{Cl}_{11}$-DP were $0.83,0.24,1.05,0.81$ and 0.30 , respectively. The one-sample $T$-test analysis revealed that L/M was not significantly different from 1 for syn-DP, Mirex and Dec $602(p>0.05)$, but $\mathrm{L} / \mathrm{M}$ ratios for anti-DP and anti- $\mathrm{Cl}_{11^{-}}$DP were significantly less than $1(p<0.05)$. The result demonstrated there was no distribution discrimination between the liver and muscle tissue for syn-DP, Mirex and Dec 602, but higher retention of anti-DP and anti-Cl $\mathrm{Cl}_{11}$-DP in frog muscle. The shorter elimination half-life of anti-DP than syn-DP (Tomy et al., 2008) may account for the lower anti-DP ratio of $\mathrm{L} / \mathrm{M}$. Limited data was available on the bioaccumulation and tissue distribution of anti- $\mathrm{Cl}_{11}$-DP. However, anti- $\mathrm{Cl}_{11}$-DP was obtained only through the loss of one chlorine atom from anti-DP. Their similar stereostructural characteristics were possibly responsible for the close $\mathrm{L} / \mathrm{M}$ value between the two compounds.

For the L/B ratio, the geometric means of syn-DP, antiDP, Mirex, Dec 602 and anti-Cl $\mathrm{Cl}_{11}$-DP were 5.57, 3.49, $9.74,4.73$ and 8.45 , respectively. These values were much higher than unity $(p<0.05)$, indicating that DPs were 
more prone to be accumulated in liver compared with brain tissue. Preferential enrichments of syn-DP and anti-Cl $\mathrm{Cl}_{11^{-}}$ DP had been reported in the liver of contaminated fish relative to the brain tissue. However, higher concentration of anti-DP was observed in the brain compared to the liver in northern snakehead and mud carp, which was not consistent with our result (Zhang et al., 2011a). Similarly to DP bioaccumulation in liver and brain tissues of frogs in the present study, preferential enrichment of PCBs, PCDDs, PCDDs and PBDEs in liver tissue was found in herring gulls (Wan et al., 2006), fowls (Yang et al., 2011) and polar bears (Gebbink et al., 2008), which could be accounted for by the fact that the blood brain barrier in brain may hinder the transport of these pollutions into the brain tissue.

The blood brain barrier played an important role in protecting the brain from the toxins, and the molecular weight of compounds was one of the important factors in this process (Naert et al., 2007; Qin et al., 2011; Yang et al., 2011; Zhang et al., 2011a). To evaluate the influence of molecular weight, the L/B values of some prevalent compounds found in frogs were simultaneously calculated, which included BDE-47, BDE-99, BDE-153, CB-138, CB-153, CB-180, Mirex, Dec 602, $\sum$ DP and anti-Cl $1_{11}$ DP. As shown in Fig. 1, linear correlation can be seen between the $\log (\mathrm{MW})$ and $\log (\mathrm{L} / \mathrm{B})\left(R^{2}=0.42, p=0.044\right)$. With the increase of $\log (\mathrm{MW})$, the value of $\log (\mathrm{L} / \mathrm{B})$ rose consequently. This result indicated that the high molecular mass of DP (654 Da) was likely responsible for its low accumulation in the brain tissue of the frogs.

\subsection{Profile ratios of DPs in different tissues}

The fraction of anti-DP $\left(f_{a n t i}\right)$ was used to evaluate the possible stereoisomer selective enrichment of DP in biota, defined as the concentration of anti-DP divided by the sum of the concentrations of syn- and anti-DP (Tomy et

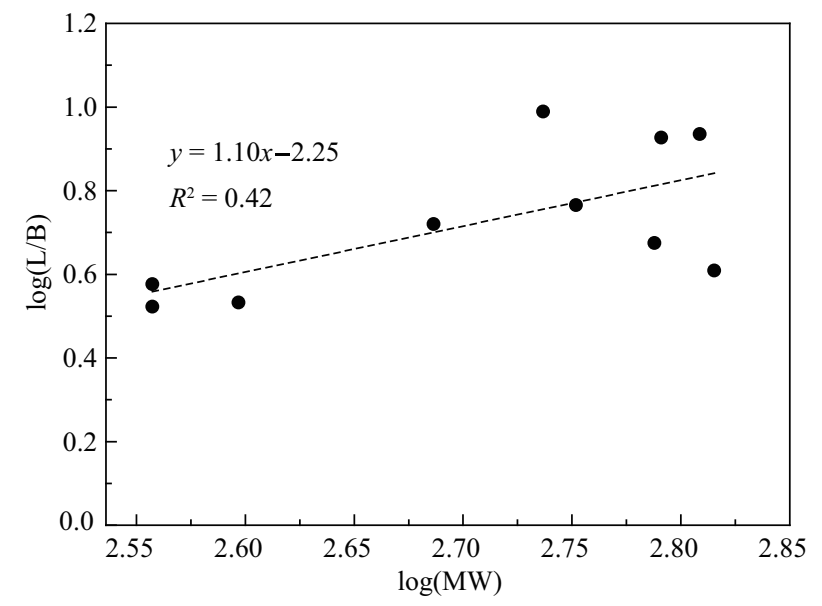

Fig. $1 \log (\mathrm{MW})$ vs. $\log (\mathrm{L} / \mathrm{B})$. MW represents the molecular mass of BDE-47, 99, 153, CB-138, 153, 180, Mirex, Dec 602, ¿DP and anti$\mathrm{Cl}_{11}$-DP. L/B represents the liver to brain concentration ratio of pollutants in frogs. al., 2007). In the present study, the means of $f_{\text {anti }}$ values in liver, muscle and brain tissues of frogs were 0.62 , $0.82,0.72$, respectively. No difference was found between $f_{\text {anti }}$ values in the muscle and the brain tissues by the Wilcoxon Signed Ranks Test. However, liver tissue showed a significantly lower $f_{\text {anti }}$ value than those in the muscle and brain tissue $(p<0.05)$, which indicated a preferential enrichment or higher retention of syn-DP in liver tissues of wild frogs. The higher assimilation efficiency and lower depuration rate of the $s y n$-isomer relative to the anti-isomer may contribute to this result (Tomy et al., 2008). Similar preferential enrichment of syn-DP was also observed in hepatic tissue of chickens (Crump et al., 2011) and bottom fishes (Zhang et al., 2011a).

The occurrence of the mono-dechlorinated DP product, anti- $\mathrm{Cl}_{11}$-DP, had been reported in biota in some studies (Sverko et al., 2008; Zheng et al., 2010; Chen et al., 2011; Zhang et al., 2011a; Peng et al., 2012). However, whether the anti- $\mathrm{Cl}_{11}$-DP originated from internal metabolism or accumulation from the external habitat environment was still unclear. In order to explore the origin of this compound in frog tissues, the ratio of anti-Cl $\mathrm{Cl}_{11}$-DP to anti-DP was employed. First, anti-Cl $\mathrm{Cl}_{11}-\mathrm{DP} /$ anti-DP in liver was not significantly different from that in muscle $(p=0.08)$, suggesting that the anti- $\mathrm{Cl}_{11}$-DP in tissues seemed to be accumulated mainly from the external environment rather than by in vivo metabolism. If internal metabolism took place, a higher ratio should be observed in liver relative to that in muscle. Similar results were also reported in mud carp liver and muscle (Zhang et al., 2011a), and in the liver of rainbow trout after DP exposure (Tomy et al., 2008). Notably, the difference of anti-Cl 11 -DP/anti-DP in liver and muscle was borderline significant $(p=0.08)$, which also implied the outcome arose from internal metabolism to some extent. This was likely related to the preferential excretion of anti-DP in liver found as described above. Additionally, the anti- $\mathrm{Cl}_{11}-\mathrm{DP} /$ anti-DP value in brain was significantly lower than those in the liver and muscle tissue $(p<0.05)$, indicating that the blood brain barrier was a greater obstacle for anti- $\mathrm{Cl}_{11}$-DP than anti-DP when they entered into the brain tissues of frogs. However, limited samples and pooled results may have had an effect on the conclusions.

\subsection{Relationship among DPs, PBDEs and PCBs}

Spearman non-parametric association analysis among DPs, PBDEs and PCBs concentrations indicated that the DP level showed no correlation with PCBs $(p>0.05)$, but significantly positive correlation with PBDEs $(p<0.05)$ (Table 2). The correlation partially might be accounted for by their different application, in that both DP and PBDEs are used widely in electric/electrical equipment as flame retardants, while PCBs are used as dielectric fluids in transformers, capacitors and coolants. Therefore, the result indicated that DP might have similar sources or environ- 
Table 2 Correlation coefficient of contaminants in frog tissues by Spearman non-parametric association analysis

\begin{tabular}{lllllll} 
& PBDE & PCB & Mirex & Dec 602 & $\sum$ DP & Anti-Cl $_{11}$-DP \\
\hline PBDE & 1.00 & 0.33 & $0.62^{*}$ & $0.90^{* *}$ & $0.90^{* *}$ & $0.92^{* *}$ \\
PCB & & 1.00 & $0.60^{* *}$ & 0.47 & 0.45 & 0.40 \\
Mirex & & & 1.00 & $0.64^{*}$ & 0.46 & 0.39 \\
Dec 602 & & & & 1.00 & $0.93^{* *}$ & $0.88^{* *}$ \\
$\sum$ DP & & & & & 1.00 & $0.96^{* *}$ \\
Anti-Cl ${ }_{11}$-DP & & & & & & 1.00 \\
\hline
\end{tabular}

* Correlation is significant at the 0.05 level (2-tailed); ${ }^{* *}$ correlation is significant at the 0.01 level (2-tailed).

mental behavior to PBDEs, but different from PCBs in our study. Similar speculation from the significant association of DP and PBDEs was also reported in waterbirds collected from Qingyuan County, another e-waste recycling site in South China (Zhang et al., 2011b), and in franciscana dolphin from the southeastern and southern coast of Brazil (de la Torre et al., 2012).

No relationship was found between Mirex and DP, but Dec 602 was positively related with both DP and PBDEs $(p<0.05)$. Their different applications may be responsible for these results. Dec 602, similar to PBDEs and DP, was used as a flame retardant in electronic/electrical products. However, Mirex was used as both flame retardant and pesticide. The dual application of Mirex resulted in mixed sources for frogs.

In brief, considered the prevailing e-waste recycling activities in Taizhou and the significant correlation between Dechloranes and PBDEs, the activities of recycling ewaste containing PBDEs might be one of sources of DPs found in wild frogs. This speculation is consistent with the result reported by Ren et al. (2009), which suggested that e-waste recycling activities were a major DP source in the e-waste recycling region.

\section{Conclusions}

The frequent detection of Dechloranes in wild frog tissues highlighted Dechlorane pollution in wildlife from an e-waste recycling region in Taizhou, China. Tissue distribution discrimination was found for anti-DP and anti$\mathrm{Cl}_{11}$-DP with higher concentration in the muscle tissue relative to the liver tissue. The blood brain barrier showed hindrance when these pollutants were deposited in brain tissue. The isomeric profile of DP indicated that stereoselective bioaccumulation of DP occurred in the wild frogs. Furthermore, the e-waste recycling activity was speculated to be an important source of DPs in wild frogs. Overall, our results showed some differences in tissue distribution and stereoisomer selective enrichment of DP among amphibians, aquatic and terrestrial biota.

\section{Acknowledgments}

This work was supported by the National Natural Science Foundation of China (No. 21177152, 20877092) and the Chinese Academy of Sciences (No. YSW2013B01)).

\section{R E F E R E N C E S}

Ben, Y.J., Li, X.H., Yang, Y.L., Li, L., Di, J.P., Wang, W.Y. et al., 2013. Dechlorane Plus and its dechlorinated analogs from an e-waste recycling center in maternal serum and breast milk of women in Wenling, China. Environ. Poll. 173, 176-181.

Burkhart, J.G., Ankley, G., Bell, H., Carpenter, H., Fort, D., Gardiner D. et al., 2000. Strategies for assessing the implications of malformed frogs for environmental health. Environ.Health Perspect. 108(1), 83-90.

Chen, S.J., Tian, M., Wang, J., Shi, T., Luo, Y., Luo, X.J. et al., 2011. Dechlorane Plus (DP) in air and plants at an electronic waste (ewaste) site in South China. Environ. Poll. 159(5), 1290-1296.

Crump, D., Chiu, S., Gauthier, L.T., Hickey, N.J., Letcher, R.J., Kennedy, S.W., 2011. The effects of Dechlorane Plus on toxicity and mRNA expression in chicken embryos: a comparison of in vitro and in ovo approaches. Comp. Biochem. Physiol. C-Toxicol. Pharmacol. 154(2), 129-134.

de la Torre, A., Alonso, M.B., Martinez, M.A., Sanz, P., Shen, L., Reiner, E.J. et al., 2012. Dechlorane-related compounds in franciscana dolphin (Pontoporia blainvillei) from Southeastern and Southern Coast of Brazil. Environ. Sci. Technol. 46(22), 12364-12372.

de Solla, S.R., Bishop, C.A., Pettit, K.E., Elliott, J.E., 2002. Organochlorine pesticides and polychlorinated biphenyls (PCBs) in eggs of red-legged frogs (Rana aurora) and northwestern salamanders (Ambystoma gracile) in an agricultural landscape. Chemosphere 46(7), 1027-1032.

Feo, M.L., Baron, E., Eljarrat, E., Barcelo, D., 2012. Dechlorane Plus and related compounds in aquatic and terrestrial biota: a review. Anal. Bioanal. Chem. 404(9), 2625-2637.

Gauthier, L.T., Hebert, C.E., Weseloh, D.V.C., Letcher, R.J., 2007. Current-use flame retardants in the eggs of herring gulls (Larus argentatus) from the Laurentian Great lakes. Environ. Sci. Technol. 41(13), 4561-4567.

Gebbink, W.A., Sonne, C., Dietz, R., Kirkegaard, M., Riget, F.F., Born E.W. et al., 2008. Tissue-specific congener composition of organohalogen and metabolite contaminants in East Greenland polar bears (Ursus maritimus). Environ. Poll. 152(3), 621-629.

Guerra, P., Fernie, K., Jimenez, B., Pacepavicius, G., Shen, L., Reiner, E. et al., 2011. Dechlorane Plus and related compounds in peregrine falcon (Falco peregrinus) eggs from Canada and Spain. Environ. Sci. Technol. 45(4), 1284-1290.

Jia, H.L., Sun, Y.Q., Liu, X.J., Yang, M., Wang, D.G., Qi, H. et al., 2011. Concentration and bioaccumulation of Dechlorane compounds in coastal environment of Northern China. Environ. Sci. Technol. 45(7), 2613-2618.

Kang, J.H., Kim, J.C., Jin, G.Z., Park, H., Baek, S.Y., Chang, Y.S., 2010. Detection of Dechlorane Plus in fish from urban-industrial rivers. Chemosphere 79(8), 850-854.

Kannan, K., Tao, L., Sinclair, E., Pastva, S.D., Jude, D.J., Giesy, J.P., 2005. Perfluorinated compounds in aquatic organisms at various trophic levels in a Great Lakes food chain. Arch. Environ. Contam. 
Toxicol. 48(4), 559-566.

Liu, P.Y., Du, G.D., Zhao, Y.X., Mu, Y.S., Zhang, A.Q., Qin, Z.F. et al., 2011. Bioaccumulation, maternal transfer and elimination of polybrominated diphenyl ethers in wild frogs. Chemosphere 84(7), 972-978.

Naert, C., Van Peteghem, C., Kupper, J., Jenni, L., Naegeli, H., 2007. Distribution of polychlorinated biphenyls and polybrominated diphenyl ethers in birds of prey from Switzerland. Chemosphere 68(5), 977-987.

Peng, H., Zhang, K., Wan, Y., Hu, J.Y., 2012. Tissue distribution, maternal transfer, and age-related accumulation of Dechloranes in Chinese Sturgeon. Environ. Sci. Technol. 46(18), 9907-9913.

Pezdirc, M., Heath, E., Mali, L.B., Bulog, B., 2011. PCB accumulation and tissue distribution in cave salamander (Proteus anguinus anguinus, Amphibia, Urodela) in the polluted karstic hinterland of the Krupa River, Slovenia. Chemosphere 84(7), 987-993.

Qin, X.F., Qin, Z.F., Li, Y., Zhao, Y.X., Xia, X.J., Yan, S.S. et al., 2011. Polybrominated diphenyl ethers in chicken tissues and eggs from an electronic waste recycling area in southeast China. J. Environ. Sci. 23(1), 133-138.

Ren, G.F., Yu, Z.Q., Ma, S.T., Li, H.R., Peng, P.G., Sheng G.Y. et al., 2009. Determination of Dechlorane Plus in serum from electronics dismantling workers in South China. Environ. Sci. Technol. 43(24), 9453-9457.

Schlabach, M., Remberger, M., Brorstrm-Lundn, E., Norstrm, K., Kaj, L., Andersson, A. et al., 2011. Brominated Flame Retardants (BFR) in the Nordic Environment. Nordic Council of Ministers, Copenhagen.

Shen, L., Reiner, E.J., Helm, P.A., Marvin, C.H., Hill, B., Zhang, X.M. et al., 2011. Historic trends of Dechloranes 602, 603, 604, Dechlorane Plus and other norbornene derivatives and their bioaccumulation potential in Lake Ontario. Environ. Sci. Technol. 45(8), 33333340 .

Shen, L., Reiner, E.J., MacPherson, K.A., Kolic, T.M., Sverko, E., Helm, P.A. et al., 2010. Identification and screening analysis of halogenated norbornene flame retardants in the Laurentian Great Lakes: Dechloranes 602, 603, and 604. Environ. Sci. Technol. 44(2), 760-766

Subring, R., Moller, A., Freese, M., Pohlmann, J.D., Wolschke, H., Sturm, R. et al., 2013. Brominated flame retardants and Dechloranes in eels from German rivers. Chemosphere 90(1), 118-124.

Sun, Y.X., Luo, X.J., Wu, J.P., Mo, L., Chen, S.J., Zhang, Q. et al., 2012. Species- and tissue-specific accumulation of Dechlorane Plus in three terrestrial passerine bird species from the Pearl River Delta, South China. Chemosphere 89(4), 445-451.

Sverko, E., Reiner, E.J., Tomy, G.T., McCrindle, R., Shen, L., Arsenault, G. et al., 2010. Compounds structurally related to Dechlorane Plus in sediment and biota from Lake Ontario (Canada). Environ. Sci. Technol. 44(2), 574-579.

Sverko, E., Tomy, G.T., Marvin, C.H., Zaruk, D., Reiner, E., Helm, P.A. et al., 2008. Dechlorane Plus levels in sediment of the lower Great Lakes. Environ. Sci. Technol. 42(2), 361-366.

Sverko, E., Tomy, G.T., Reiner, E.J., Li, Y.F., McCarry, B.E., Arnot, J.A. et al., 2011. Dechlorane Plus and related compounds in the environment: a review. Environ. Sci. Technol. 45(12), 5088-5098.

Tomy, G.T., Pleskach, K., Ismail, N., Whittle, D.M., Helm, P.A., Sverko E. et al., 2007. Isomers of Dechlorane Plus in Lake Winnipeg and Lake Ontario food webs. Environ. Sci. Technol. 41(7), 2249-2254.

Tomy, G.T., Thomas, C.R., Zidane, T.M., Murison, K.E., Pleskach, K., Hare, J. et al., 2008. Examination of isomer specific bioaccumulation parameters and potential in vivo hepatic metabolites of syn- and anti-Dechlorane Plus isomers in juvenile rainbow trout (Oncorhynchus mykiss). Environ. Sci. Technol. 42(15), 5562-5567.

Wan, Y., Hu, J., An, W., Zhang, Z., An, L., Hattori, T. et al., 2006. Congener-specific tissue distribution and hepatic sequestration of PCDD/Fs in wild herring gulls from Bohai Bay, North China: comparison to coplanar PCBs. Environ. Sci. Technol. 40(5), 14621468.

Wu, J.P., Luo, X.J., Zhang, Y., Chen, S.J., Mai, B.X., Guan, Y.T. et al., 2009. Residues of polybrominated diphenyl ethers in frogs (Rana limnocharis) from a contaminated site, South China: tissue distribution, biomagnification, and maternal transfer. Environ. Sci. Technol. 43(14), 5212-5217.

Wu, J.P., Zhang, Y., Luo, X.J., Chen, S.J., Mai, B.X., 2012. DDTs in rice frogs (Rana limnocharis) from an agricultural site, South China: tissue distribution, biomagnification, and potential toxic effects assessment. Environ. Toxicol. Chem. 31(4), 705-711.

Wu, J.P., Zhang, Y., Luo, X.J., Wang, J., Chen, S.J., Guan, Y.T. et al., 2010. Isomer-specific bioaccumulation and trophic transfer of Dechlorane Plus in the freshwater food web from a highly contaminated site, South China. Environ. Sci. Technol. 44(2), 606611.

Xian, Q.M., Siddique, S., Li, T., Feng, Y.L., Takser, L., Zhu, J.P., 2011. Sources and environmental behavior of Dechlorane Plus - a review. Environ. Int. 37(7), 1273-1284.

Yang, Z.Z., Li, Y.F., Fu, S., Zhao, X.R., 2011. Special distribution of polybrominated diphenyl ethers in brain tissues of free-range domestic hens and ducks from a village near an electronic waste recycling site in South China. Bull. Environ. Contam. Toxicol. 86(3), 283-288.

Zhang, X.L., Luo, X.J., Liu, H.Y., Yu, L.H., Chen, S.J., Mai, B.X., 2011b. Bioaccumulation of several brominated flame retardants and Dechlorane Plus in waterbirds from an e-waste recycling region in South China: associated with trophic level and diet sources. Environ. Sci. Technol. 45(2), 400-405.

Zhang, X.L., Yang, F.X., Wen, S., Jin, S.W., Hui, Y., Xu, Y., 2009. Congener pattern and toxicity of polychlorinated biphenyls in aquatic organisms from an electronic and electrical waste area. Acta Hydrob. Sinica, 33(5), 811-817.

Zhang, Y., Wu, J.P., Luo, X.J., Wang, J., Chen, S.J., Mai, B.X., 2011a. Tissue distribution of Dechlorane Plus and its dechlorinated analogs in contaminated fish: high affinity to the brain for anti-DP. Environ. Pollut. 159(12), 3647-3652.

Zheng, J., Wang, J., Luo, X.J., Tian, M., He, L.Y., Yuan, J.G. et al., 2010. Dechlorane Plus in human hair from an e-waste recycling area in South China: comparison with dust. Environ. Sci. Technol. 44(24), 9298-9303. 